\title{
Perlakuan Panas untuk Mengurangi Gejala Kerusakan Dingin pada Mangga (Mangifera indica L.) var. Gadung selama Penyimpanan pada Suhu Rendah
}

\section{Heatshock Treatment in Reducing Chilling Injury Symptoms on Mangoes (Mangifera indica L.) cv. Gadung during Low Temperature Storage}

\author{
Gysberth Pattiruhu, Y Aris Purwanto*, dan Emmy Darmawanty \\ Departemen Teknik Mesin dan Biosistem, Fakultas Teknologi Pertanian, Institut Pertanian Bogor \\ (Bogor Agriculture University), Kampus IPB Dramaga, Bogor 16680, Indonesia. \\ *Penulis untuk koresponden. email: arispurwanto@gmail.com
}

Diterima 11 November 2016/Disetujui 9 Januari 2017

\begin{abstract}
Mango (Mangifera indica L.) is perishable horticulture product. Commercially, mango fruits are harvested at the mature-green stage of development and are handled at low temperatures to facilitate shipping. However, long term low temperature storage of mature-green mango fruits is currently risky because of chilling injury (CI). The ojective of this study was to examine quality changes of mango during storage at $8^{\circ} \mathrm{C}$ after heatshock treatment. Heatshock treatment consist of hot water treatment (HWT) at temperature of $55^{\circ} \mathrm{C}$ in 3 and 10 minutes and intermittent warming (IW) at temperature $20^{\circ} \mathrm{C}$ for 1 day after 2 and 3 days of low temperature storage. The result showed that HWT of $55^{\circ} \mathrm{C}$ in 3 minutes could decrease of weight loss and maintain the quality and chemical content of mango during storage at low temperatures. While IW treatment after 2 and 3 days at low temperature storage in this study was not effective in reducing chilling injury and maintaining quality of mango.
\end{abstract}

Keywords: chilling injury, hetshock treatment,low temperature storage, mango.

\section{ABSTRAK}

Mangga (mangifera indica L.) termasuk produk pertanian yang memiliki sifat mudah rusak dan mengalami susut. Penanganan pascapanen menggunakan suhu dingin dapat mempertahankan umur simpan dan mengurangi susut. Namun, penyimpanan menggunakan suhu rendah dapat menyebabkan kerusakan dingin (chilling injury), dan menurunkan mutu dari buah mangga. Penelitian ini bertujuan untuk mengkaji perubahan mutu dan chilling injury pada buah mangga setelah diberikan perlakuan panas pada penyimpanan dengan suhu $8^{\circ} \mathrm{C}$. Perlakuan panas terdiri dari HWT pada suhu $55{ }^{\circ} \mathrm{C}$ selama 3 dan 10 menit, IW pada suhu $20^{\circ} \mathrm{C}$ selama 1 hari setelah 2 dan 3 hari penyimpanan. Hasil penelitian menunjukkan pemberian HWT selama 3 menit mampu mengurangi terjadinya kerusakan dingin dan menjaga mutu dan kandungan kimia buah mangga selama penyimpanan pada suhu rendah dibandingkan HWT selama 10 menit. Sedangkan perlakuan IW setelah 2 hari atau 3 hari dalam penelitian ini tidak efektif dalam mengurangi kerusakan dingin dan mempertahankan kualitas dari buah mangga selama penyimpanan pada suhu rendah.

Kata kunci: kerusakan dingin, mangga, perlakuan panas, penyimpanan suhu rendah.

\section{PENDAHULUAN}

Mangga merupakan tanaman buah tahunan berupa pohon yang berasal dari negara India, yang kemudian menyebar ke wilayah Asia Tenggara termasuk Malaysia dan Indonesia (FAO 2005). Penanganan pascapanen di Indonesia belum memadai sehingga mengakibatkan kualitas buah yang dihasilkan rendah dan kehilangan hasil buah segar. Dalam melakukan penanganan pascapanen pada buah mangga membutuhkan pengetahuan pascapanen yang fisiologi buah dan pemahaman tentang bagaimana menentukan penanganan untuk mempertahankan dan mengembangkan kualitas buah yang tinggi (Yahia, 2005; Brecht dan Yahia, 2009). Salah satu penanganan pascapanen yang dapat diupayakan adalah penyimpanan dengan menggunakan suhu rendah.

Penyimpanan dingin dimaksudkan untuk menurunkan suhu produk sehingga dapat memperlambat laju respirasi. Secara teoritis, semakin rendah suhu penyimpanan, kemampuan respirasi buah-buahan segar dapat semakin dihambat (Fennir et al. 2003). Karena pada suhu penyimpanan rendah, solubiditas dari cairan dalam sel buah-buahan akan semakin tinggi yang dapat menekan proses respirasi produk (Purwanto et al., 2005). Tetapi penyimpanan dingin dengan suhu yang tidak tepat dapat menyebabkan chilling injury dan membuat mutu produk menjadi menurun dan akan berpengaruh pada nilai jualnya. 
Beberapa penanganan pascapanen panas (heat treatment) telah digunakan untuk memodifikasi produk yang stres terkena pendinginan dibawah suhu optimum dan menjaga kualitas buah selama penyimpanan. Penanganan pascapanen panas dapat dilakukan hanya beberapa menit pada suhu 40-60 ${ }^{\circ} \mathrm{C}$ dengan perendaman dalam air panas (hot water treatment) atau dapat dilakukan dengan pemberian suhu hangat dalam waktu beberapa jam atau hari pada suhu 20-40 ${ }^{\circ} \mathrm{C}$ yang disebut intermittent warming. Penanganan ini ditujukan untuk mengurangi tingkat kerusakan dingin (Lurie dan Pedreschie, 2014). Penelitian ini bertujuan untuk mengkaji perubahan mutu fisik dan chilling injury pada buah mangga setelah diberikan perlakuan HWT dan IW.

\section{BAHAN DAN METODE}

Penelitian ini dilakukan di laboratorium Teknologi Pengolahan dan Pengkajian Hasil Pertanian (TPPHP) Departemen Teknologi Mesin dan Biositem, Fakultas Teknologi Pertanian, Kampus IPB, Dramaga, Bogor, menggunakan rancangan acak kelompok dan diulang sebanyak 2 kali. Percobaan terdiri atas tiga kelompok yaitu lama pemberian heatshock pada kelompok HWT pada suhu $55{ }^{\circ} \mathrm{C}$, IW pada suhu $20{ }^{\circ} \mathrm{C}$ dan kontrol. Kelompok HWT terdiri dari 2 taraf yaitu selama 3 menit dan selama 10 menit. Begitu juga dengan IW pada suhu $20{ }^{\circ} \mathrm{C}$ terdiri dari 2 taraf dengan lama penyimpanan 2 hari dan 3 hari.

Pengamatan dilakukan terhadap parameter mutu dan kimia yaitu susut bobot, kekerasan kulit buah mangga, perubahan warna, $\mathrm{CI}$ index, total padatan terlarut, total asam tertitrasi buah mangga diukur setiap 3 hari sekali setelah diberi perlakuan. Dan untuk kandungan kimia lainnya yaitu kadar air, kandungan bahan kering dan kadar serat diukur 5 hari sekali setelah diberi perlakuan.

\section{HASIL DAN PEMBAHASAN}

\section{Index Chilling Injury Mangga}

Chilling injury (CI) adalah kerusakan yang terjadi karena penyimpanan pada suhu dibawah optimum, dan dapat dicirikan dengan adanya bintik/bercak hitam atau cokelat pada kulit buah, pembentukan warna yang tidak sempurna dan pematangan yang tidak normal (Nair et al. 2003). CI dapat terjadi karena adanya kerusakan pada tingkat sel yang disebabkan oleh penurunan kelarutan asam lemak tak jenuh pada membran lipid sehingga dapat mengakibatkan mengkerutnya kulit buah, terdapat lubang pada permukaan buah.

Pengamatan munculnya CI pada buah mangga ditandai dengan pematangan tidak normal, bintik-bintik hitam dan cokelat pada kulit buah mangga. Gambar 1 menyajikan perubahan indeks CI selama 24 hari penyimpanan dingin. Tingkat kerusakan dingin buah yang diberi perlakuan perendaman air panas (HWT) selama penyimpanan lebih rendah dibandingkan dengan perlakuan lainnya. Penyimpanan mangga pada suhu $8^{\circ} \mathrm{C}$ untuk semua perlakuan mengalami CI pada hari ke-3. CI index yang terjadi pada

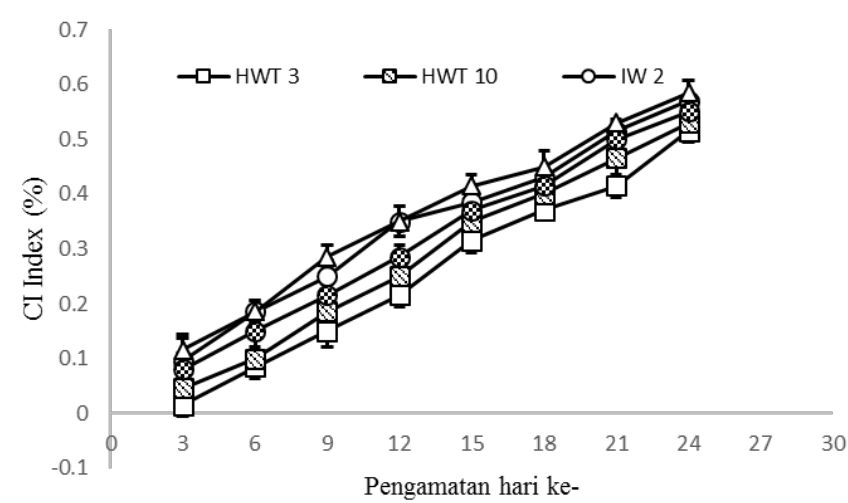

Gambar 1. Perubahan index chilling injury selama penyimpanan

hari ke-3 memberikan skor yang terendah sebesar 0.01 sampai skor yang tertinggi sebesar 0.11 .

Penelitian menunjukkan bahwa pada penyimpanan hari ke-24 perlakuan HWT selama 3 menit memiliki nilai CI yang paling rendah yaitu sebesar 0.52 dan nilai HWT selama 10 adalah 0.53 , sehingga sangat efektif untuk mengurangi tejadinya CI pada buah mangga sampai pada penyimpanan hari ke-24. Hasil ini berbeda dengan penelitian yang dilakukan oleh (Zhang et al. 2012) yang menyatakan HWT selama 10 menit pada suhu $55^{\circ} \mathrm{C}$ pada penyimpanan dingin di suhu $55^{\circ} \mathrm{C}$ lebih efektif mengurangi terjadinya chilling injury pada buah mangga Tainong 1 . Selain itu juga Ketsa et al. (2000) menyatakan bahwa heat air treatment (HAT) pada suhu $38{ }^{\circ} \mathrm{C}$ selama 3 hari pada penyimpanan $4{ }^{\circ} \mathrm{C}$ dapat mengurangi tingkat kerusakan dingin pada buah mangga. Hal ini dapat menjelaskan bahwa suhu dan waktu perendaman air panas juga berpengaruh terhadap penurunan index CI tiap varietas buah mangga. Hal tersebut juga didukung oleh pernyataan Sevillano et al. (2009) yang menyatakan bahwa HWT dengan suhu tinggi dan waktu yang singkat dapat menghindari kerusakan dingin dan tidak merusak kualitas buah.

Sementara perlakuan IW setelah penyimpanan pada suhu rendah selama 2 hari menunjukkan nilai CI yang lebih besar dibandingkan perlakuan IW setelah penyimpanan pada suhu rendah selama 3 hari yaitu sebesar 0.57 dan 0.56 . Hal ini dikarenakan perlakuan IW kurang mampu menekan penundaan penurunan kandungan asam lemak sehingga kurang mampu mempertahankan integritas membran. Siklus IW juga perlu diperhatikan, menurut Liu et al. (2015) siklus IW yang tepat sangat efektif dalam menunda penurunan kandungan asam lemak dalam mempertahankan integritas membran sel.

Untuk kontrol sendiri terjadi pematangan yang tidak normal selama penyimpanan. Hasil ini juga sesuai dengan penelitian Gomez et al. (2009) dimana buah tomat selama penyimpanan pada suhu $6{ }^{\circ} \mathrm{C}$ mengalami pematangan yang tidak normal sehingga tidak muncul warna merah. Hal ini dapat disebabkan karena terjadinya kerusakan dingin dimana suhu penyimpanan dan lamanya penyimpanan yang merupakan penyebab terjadinya kegagalan pematangan dan dapat meningkatkan terjadinya pembusukan (Cheng et al. 1988). 


\section{Susut Bobot}

Hasil penelitian menunjukkan selama penyimpanan tampak terjadi peningkatan susut bobot. Peningkatan susut bobot terjadi disebabkan karena adanya proses respirasi dan transpirasi yang mengakibatkan komoditas hortikultura akan kehilangan air melalui penguapan dan terurainya glukosa menjadi $\mathrm{CO}_{2}$ dan $\mathrm{H}_{2} \mathrm{O}$. Hasil pengukuran susut bobot dapat dilihat pada Gambar 2.

Berdasarkan hasil pengukuran susut bobot yang disajikan pada Gambar 2, peningkatan susut bobot pada penyimpanan hari ke 24 sebesar 2.99, 3.13, 3.2, 3.15 dan $3.27 \%$ masing-masing untuk HWT selama 3 menit, HWT selama 10 menit, IW setelah 2 hari, IW setelah 3 hari dan kontrol. Pada gambar 2 menunjukkan bahwa kontrol memiliki peningkatan susut bobot yang tinggi. Hal ini disebabkan pada penyimpanan dingin meskipun dapat mengurangi respirasi namun dapat menimbulkan terjadinya kerusakan dingin yang dapat mengakibatkan pengeriputan pada kulit buah yang membuat air dalam manga akan keluar dan terjadi pelunakan (Nakano et al 2002)..

Berdasarkan hasil pengukuran susut bobot yang disajikan pada Gambar 2, dapat diketahui bahwa HWT selama 3 menit mampu menekan peningkatan susut bobot lebih besar dibandingkan dengan HWT selama 10 menit. Hal ini dikarenakan suhu yang tinggi dapat mempercepat lajunya respirasi dan transpirasi.

Berbeda dengan HWT, perlakuan IW setelah penyimpanan 2 hari dan 3 hari kurang mampu menekan terjadinya peningkatan susut bobot. Hasil ini juga sesuai dengan penelitian yang telah dilakukan oleh (Artez dan Fernandez, 1997) yang menyatakan IW dapat meningkatkan susut bobot dan penuaan. Hal ini dapat disebabkan karena IW mempengaruhi oksidasi dan reaksi kimia lainnya (Meir dan Bramlage, 1988) sehingga merusak tingkat ketahanan buah dan menyebabkan penyusutan (Whitaker, 1998).

Peningkatan susut bobot berkorelasi dengan adanya chilling injury, karena kerusakan dingin mengakibatkan adanya lubang pada permukaan buah sehingga dapat mempercepat hilangnya air didalam buah. Kehilangan air yang terjadi dapat menyebabkan pengeriputan dan juga pelunakan (Nakano et al., 2002). Persentase susut bobot

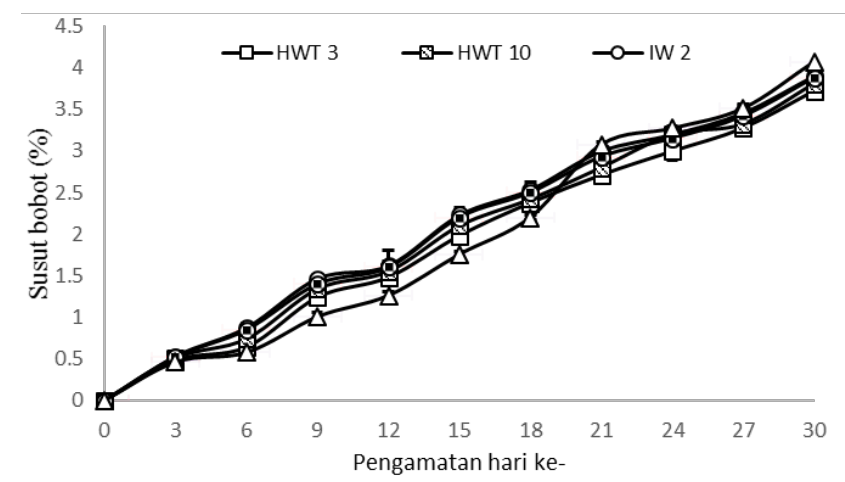

Gambar 2. Perubahan susut bobot selama penyimpanan yang rendah dapat menunjukkan bahwa suhu rendah mampu menghambat laju respirasi dan transpirasi sehinga mampu mengatasi peningkatan susut bobot.

\section{Kekerasan}

Kekerasan buah merupakan salah satu faktor penentuan kualitas yang dapat diukur secara kualitatif oleh indera perasa ataupun secara kuantitatif menggunakan rheometer. Kekerasan mangga selama penyimpanan mengalami penurunan dengan bertambahnya hari penyimpanan.

Gambar 3 menjelaskan bahwa penyimpanan tanpa perlakuan (kontrol) masih dapat mempertahankan kekerasan buah dibandingkan dengan perlakuan HWT dan IW sampai pada penyimpanan hari ke-18. Hal ini berkorelasi dengan susut bobot dan juga CI index, karena kekerasan buah mangga tergantung pada sifat dari jaringan seperti kandungan air, penyusun dasar dinding sel, dan juga terkanan turgor pada dinding sel (Arafat, 2005). Penurunan tingkat kekerasan selama penyimpanan dapat terjadi karena kerusakan pada jaringan kulit yang menyebabkan tingginya tingkat transpirasi sehingga buah menjadi keriput dan membuat daging buah menjadi lunak (Syahfutri, 2006). Penurunan kekerasan juga dapat disebabkan karena terjadinya perombakan protopektin (pektin yang tidak larut air) menjadi pektin yang larut dalam air. Selama pematangan buah, jumlah protopektin akan semakin menurun dan pektin yang larut dalam air akan meningkat sehingga membuat daging buah menjadi semakin lunak (Brummell dan Harpster, 2001).

\section{Total Asam}

Selama penyimpanan buah Mangga Gadung terjadi perubahan kandungan asam organik. Perubahan yang terjadi ditandai dengan penurunan nilai kandungan asam selama penyimpanan yang diakibatkan oleh perubahan asam sitrat menjadi gula yang digunakan sebagai substat selama respirasi (Rathore et al., 2007). Gambar 4 menunjukkan bahwa perlakuan HWT selama 3 menit memiliki nilai total asam yang cukup tinggi dari awal penyimpanan sampai pada akhir penyimpanan dibandingkan perlakuan lainnya

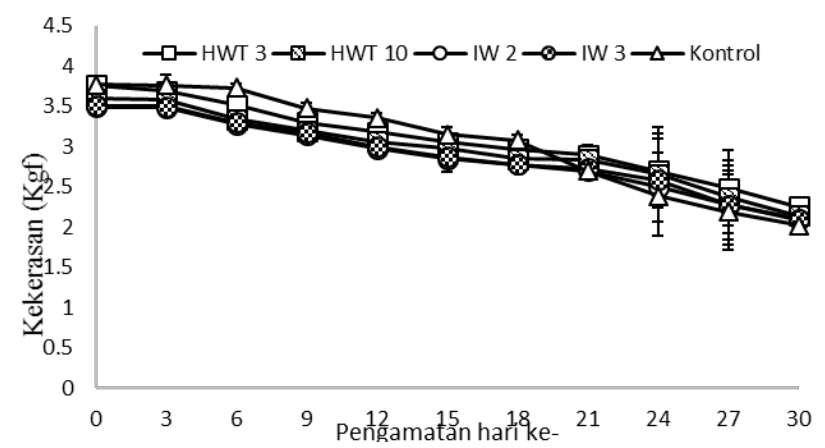

Gambar 3. Perubahan tingkat kekerasan selama penyimpanan 


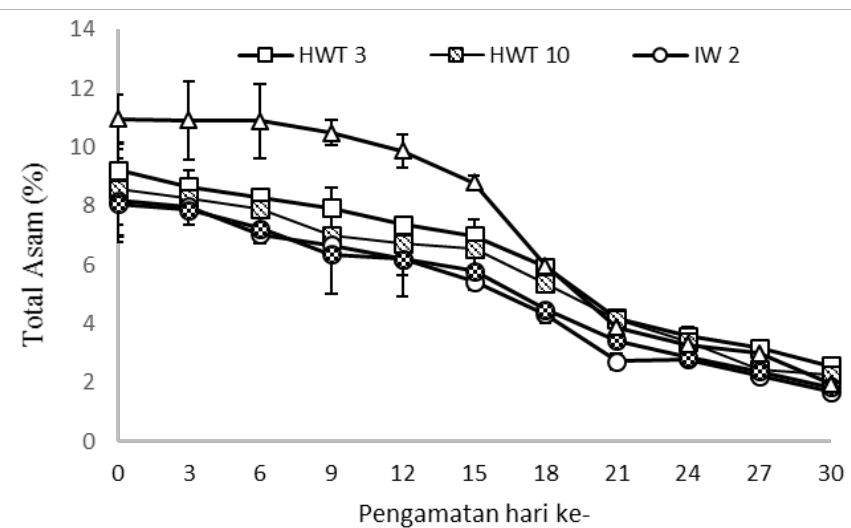

Gambar 4. Perubahan total asam selama penyimpanan

\section{Total Padatan Terlarut}

Total padatan terlarut (TPT) pada buah bisa digunakan sebagai penafsiran tingkat kemanisan, karena sebagian besar padatan terlarut yang terdapat dalam buah berupa gula (Simson dan Straus, 2010). Selama penyimpanan terjadi peningkatan total padatan terlarut yang dapat dilihat pada Gambar 5. Peningkatan total padatan terlarut ini disebabkan karena terhidrolisisnya pati menjadi senyawa yang lebih sederhana akibat adanya proses respirasi yang menunjukkan bahwa mangga telah mencapai tingkat kematangannya (Kittur et al., 2001). Penelitian ini menunjukkan peningkatan nilai total padatan terlarut pada lama penyimpanan hari ke18 dan pada hari ke-21 nilai total padatan terlarut mengalami penurunan. Penurunan yang terjadi diakibatkan setelah mencapai tingkat kematangan yang optimal, mangga akan mengalami fase lewat matang yang akan ditandai dengan menurunnya nilai kandungan gula.

\section{Kandungan Bahan Kering}

Selama penyimpanan buah mangga terjadi penurunan kadar air dan peningkatan kandungan bahan kering yang dapat dilihat pada Gambar 6 dan Gambar 7. Penurunan kadar air terjadi karena buah mengalami proses transpirasi aktif. Kehilangan kandungan air dalam buah biasanya terjadi pada hari-hari pertama penyimpanan, dimana buah akan mengalami perbedaan tekanan uap dengan

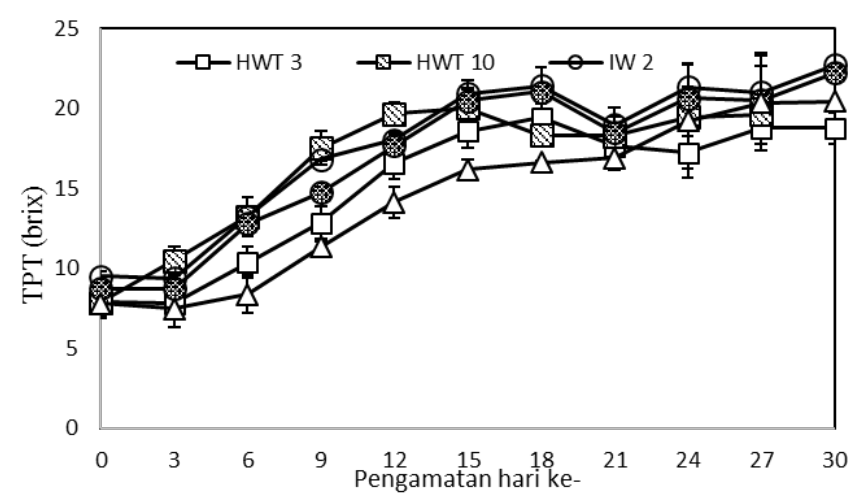

Gambar 5. Perubahan total padatan terlarut selama penyimpanan

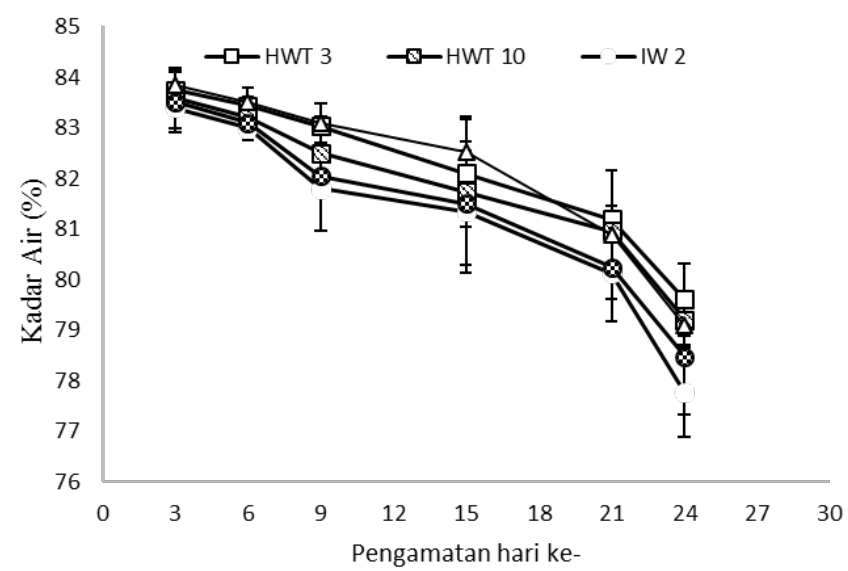

Gambar 6. Perubahan kadar air selama penyimpanan

lingkungan. Kadar air buah umumnya berkisar antara 80$90 \%$. Kehilangan kadar air tidak hanya mengurangi susut bobot, tetapi juga dapat menyebabkan penampilan jadi kurang menarik sehingga mutu buah akan menurun.

Nilai kandungan bahan kering berbanding terbalik dengan nilai kadar air, dimana jika nilai kadar air suatu bahan tinggi maka nilai kandungan bahan keringnya rendah. Penelitian ini menunjukkan bahwa nilai kadar air pada penyimpanan hari ke-24 terdapat pada perlakuan HWT selama 3 menit sebesar $79.60 \%$ memiliki nilai kandungan bahan kering sebesar $20.40 \%$. Nilai kadar air pada perlakuan HWT selama 10 menit sebesar $79.20 \%$ dengan nilai kandungan bahan kering sebesar $20.80 \%$. Hal ini dikarenakan pemberian suhu yang terlalu tinggi dan waktu yang terlalu lama akan membuat proses transpirasi berjalan dengan begitu cepat sehingga buah akan mengalami kehilangan kandungan air dalam buah. Perlakuan IW menunjukkan nilai kadar air tertinggi pada penyimpanan hari ke-24 sebesar $77.77 \%$ pada IW setelah penyimpanan selama 2 hari dan sebesar $78.48 \%$ terdapat pada IW setelah penyimpanan selama 3 hari, dengan nilai kandungan bahan kering masing-masing sebesar $22.23 \%$ dan $21.52 \%$.

\section{Kadar Serat}

Penelitian ini menunjukkan kadar serat kasar buah mangga selama penyimpanan mengalami peningkatan selama penyimpanan (Gambar 8). Serat kasar adalah serat tumbuhan yang tidak larut dalam air, dimana sangat penting

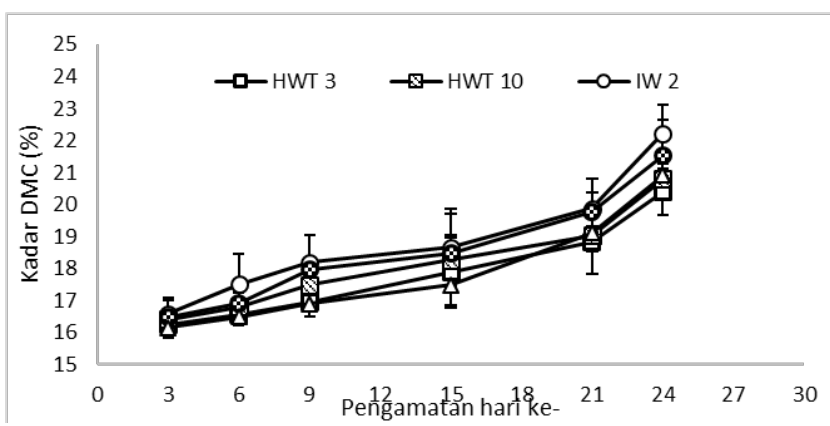

Gambar 7. Perubahan kadar DMC selama penyimpanan 


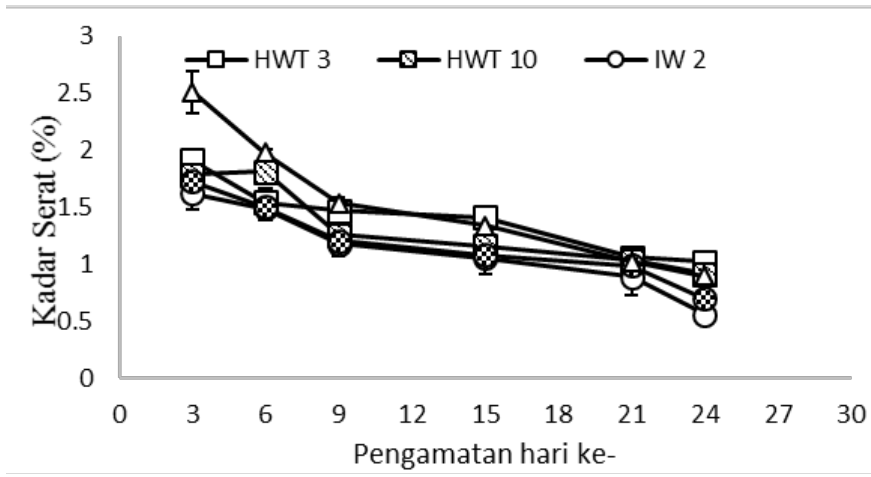

Gambar 8. Perubahan kadar serat selama penyimpanan

untuk dijadikan sebagai indeks dan menentukan nilai gizi suatu makanan. Kadar serat kasar bukanlah merupakan kadar serat makanan. Tetapi dalam kadar serat kasar pada suatu makanan dapat dijadikan sebagai indeks kadar serat makanan, karena umumnya didalam serat kasar dapat ditemukan sebanyak 0.2-0.5 bagian jumlah serat makanan. Hasil penelitian memperlihatkan buah tanpa perlakuan memiliki nilai serat yang tinggi dibandingkan perlakuan lainnya yaitu sebesar $2.51 \%$.

\section{Warna}

Selama penyimpanan terjadi perubahan warna kulit buah mangga Gadung. Perubahan warna dapat menentukan tingkat kematangan buah, dan biasanya tanda kematangan yang terjadi adalah dengan hilangnya warna hijau. Pengamatan warna terhadap buah Mangga Gadung dilakukan dengan mengukur warna dari banyaknya cahaya yang dipantulkan dengan menggunakan alat chromameter. Pengamatan dengan menggunakan chromameter dinyatakan dalam 3 parameter yaitu L*, a*, dan $b^{*}$. Nilai L* menyatakan kecerahan (cahaya yang dipantulkan menghasilkan warna akromatik putih, abu-abu, dan hitam) dengan nilai 0 (hitam) dan 100 (putih). Semakin nilai L* menunjukkan kecerahan buah semakin gelap dan sebaliknya semakin tinggi nilainya berarti semakin cerah buah selama penyimpanan. Perubahan nilai L* (lightness) dapat dilihat pada Gambar 9.

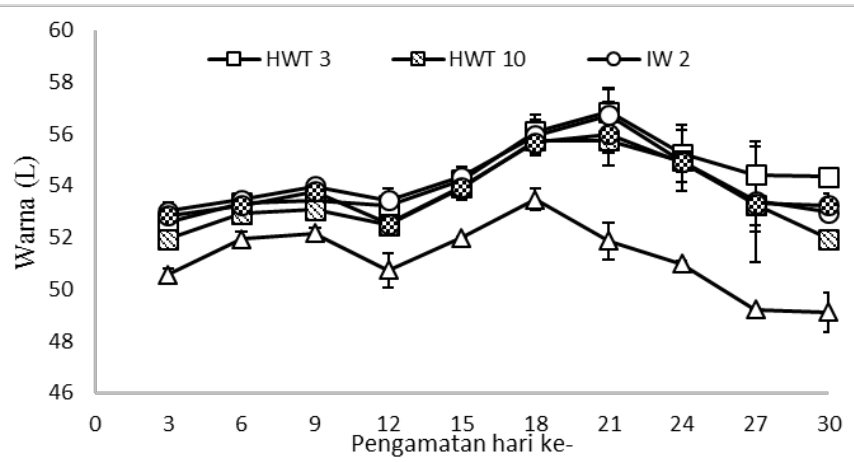

Gambar 9. Perubahan nilai kecerahan (lightness) selama penyimpanan
Gambar 9 menunjukkan selama penyimpanan terjadi peningkatan kecerahan sampai pada penyimpanan hari ke24 pada tiap perlakuan. Dan peningkatan kecerahan terlihat pada perlakuan HWT selama 3 menit. Hal ini dapat dilihat pada nilai kecerahan dari HWT selama 3 menit lebih besar dibandingkan dengan HWT selama 10 menit. Hal ini diduga berkaitan dengan perlakuan panas yang diberikan dimana pada perlakuan HWT selama 10 menit menyebabkan kerusakan membran sel lebih cepat dibandingkan dengan perlakuan HWT selama 3 menit.

Nilai a* menyatakan warna kromatik campuran merah hijau dengan nilai +a dari 0 sampai 100 menunjukkan warna merah dan -a dari 0 sampai -80 menunjukkan warna hijau. Gambar 10 menunjukkan nilai a* buah mangga selama penyimpanan mengalami peningkatan dari nilai negatif menuju nilai positif. Perlakuan HWT selama 3 menit memberikan perubahan terhadap nilai $\mathrm{a}^{*}$ yang paling rendah. Hal ini diduga karena perlakuan HWT mampu menghambat proses pematangan lebih besar dibandingkan dengan perlakuan lainnya, dimana laju respirasi dan transpirasi dihambat.

Nilai b* menyatakan warna kromatik campuran kuning biru dengan nilai $+\mathrm{b}$ antara 0 sampai +70 untuk warna kuning dan nilai -b antara 0 sampai -70 menunjukkan warna biru. Gambar 11 menunjukkan peningkatan nilai $b^{*}$ terendah terdapat pada perlakuan HWT selama 3 menit. Hal ini diduga berkaitan dengan kemampuan HWT dalam menghambat proses pematangan dengan menghambat respirasi dan transpirasi.

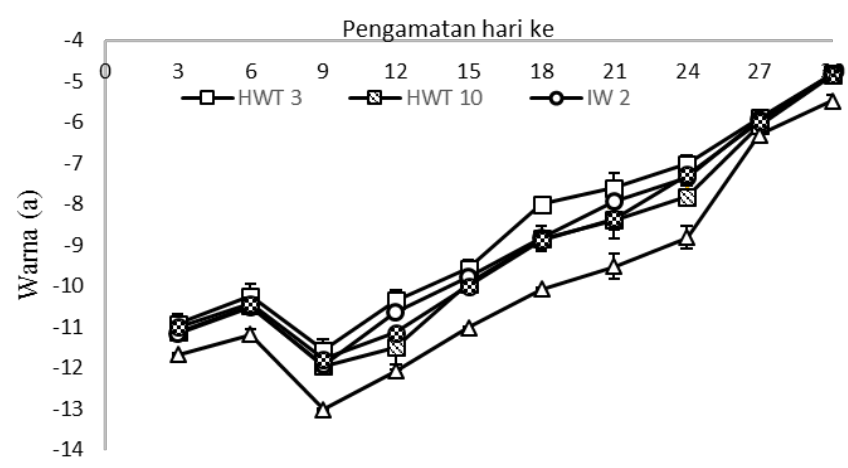

Gambar 10. Perubahan warna (a) selama penyimpanan

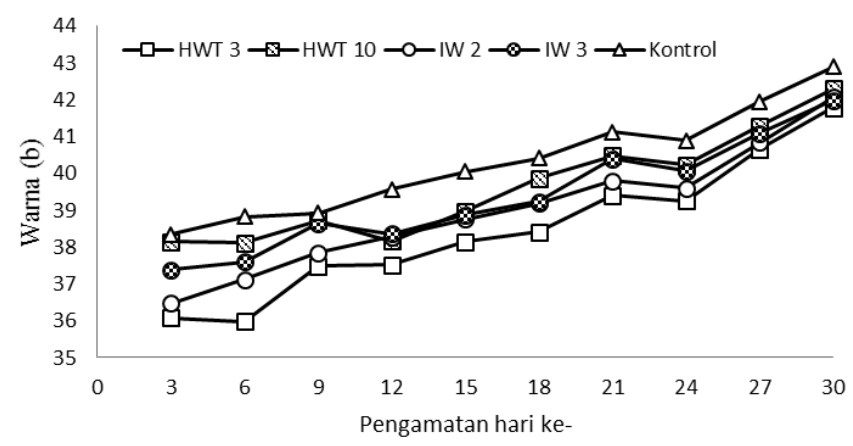

Gambar 11. Perubahan warna (b) selama penyimpanan 


\section{KESIMPULAN}

Heatshock treatment sangat berpengaruh dalam mengurangi kerusakan dingin (chilling injury). Perlakuan HWT pada suhu $55^{\circ} \mathrm{C}$ selama 3 menit mampu mengurangi terjadinya kerusakan dingin, mengurangi peningkatan susut bobot, mempertahankan kekerasan, dan mempertahankan warna. Perlakuan HWT selama 3 menit mampu mempertahankan parameter kimianya sampai pada hari ke24 seperti total padatan terlarut, total asam tertitrasi, kadar air, kandungan bahan kering, dan kadar serat. Perlakuan IW tidak memberikan pengaruh dalam mengurangi kerusakan dingin dan mempertahankan mutu dari buah mangga.

\section{DAFTAR PUSTAKA}

Arafat, L.A.E.T. 2005. Chilling injury in mangoes. Netherlands: Wageningen University.

Artes, F., J.P. Fernandez-Trujillo. 1997. Keeping quality of cold stored peaches using intermittent warming. J. Food Research International. Vol 30 (6):441-450.

Brecht, J., E.M. Yahia. 2009. Postharvest physiology. In Litz R (Ed). The Mango: Botany, Production and Uses. CAB International, Wallingford, UK, second edition, 484-528.

Brummell, D.A., M.H. Harpster. 2001. Cell wall metabolism in fruit softening and quality and its manipulation in transgenic plant. Plant Mol Biol. 47: 311-339.

Cheng, T.S., J.D. Floros, R.L. Shewfelt, C.J. Chang. 1988. The effect of high-temperature stress on ripening of tomatoes (Lycopersicon esculentum). J. Plant Physiol. 132: 459-464.

Fennir, M.A. Landry, J.A. Raghavan, G.S.V. 2003. Respiration rate of potatoes (Solanum tuberosum L.) measured in a two-bin research scale storage facility, using heat and moisture balance and GC analysis. Can Biosyst Engi. 45: 4.1-4.9.

Food and Agriculture Organization. 2005. FAOSTAT database collections, agricultural data, food and agriculture organization of the United Nation.

Gomez, P., M.A. Ferrer, J.P. Fernandez-Trujilo, A. Calderon, F. Artez, M. Ega-Cortines, J. Weiss. 2009. Structural changes, chemical compositions and antioxidant activity of cherry tomato fruits cv "Micro-Tom" stored under optimal and chilling conditions. J. Sci. Food Agr. 89:1543-1551.

Ketsa S., S. Chidtragool, S. Lurie. 2000. Prestorage heat treatment and postharvest quality of mango fruit. HortScience 35: 247-249.
Kittur, F.S. Saroja, N. Habibunnisa, N. Tharanathan, R.N. 2001. Polysaccharide-based composite coating formulations for shelf-life extension of fresh banana and mango. European Food Research and Technology 213: 306-311.

Liu, L., Y. Wei, F. Shi, C. Liu, X. Liu, S. Ji. 2015. Intermittent warming improves postharvest quality of bell peppers and reducing chilling injury. J. Postharvest Biology and Technology 101: 18-25.

Lurie, S., R. Pedreschi. 2014. Fundamental aspects of postharvest heat treatments. Horticulture Research 1, Article number: 14030 .

Meir. S, Bramlage, W.J. 1988. Antioxidant activity in Cortland apple peel and susceptibility to superficial scald after storage. J. Am. Soc. Hort. Sci. 113: 412418.

Nair, S., Z. Singh, S.C. Tan. 2003. Aroma volatiles emissions in relation to chilling injury in 'Kensington Pride' mango fruit. J. Hort. Sci. Biotechnol. 2003: 866873.

Nakano, R., S. Inoue, Y. Kubo, A. Inaba. 2002. Water stress-induced ethylene in the calyx triggers autocatalyc ethylene production and fruit softening in 'Tonewase' persimmon grown in a heated plastichouse. Postharvest Biol. Technol. 25:293-300.

Purwanto, Y.A., S. Oshita, Y. Kawagoe, Y. Makino. 2005. Determination of chilling injury index in cucumber fruits through proton NMR analysis. Peer reviewed paper International Conference on Research Highlights and Vanguard Technology on Environmental Engineering in Agricultural System. September 12-15, 2005, Kanazawa, Japan.

Rathore, H.A., T. Masud, S. Sammi, A.H. Soomro. 2007. Effect of storage on physicohemical composition and sensory properties of mango (Mangifera indica L.) variety Dosehri. Pakistan Journal of Nutrition 6:143148.

Sevillano, L. B.M.T. Sanchez, F. Romojaro, F.B. Flores. 2000. Physiological, hormonal and molecular mechanisms regulating chilling injury in horticultural species. Postharvest technologies applied to reduce its impact. J. Sci. Food Agric. 89: 555-573.

Simson, S.P., M.C. Straus. 2010. Basics of Horticulture. India: Oxford Book Company.

Syahfutri, M. 2006. Sifat fisik dan kimia buah mangga (Mangifera indica) selama penyimpanan dengan berbagai metode pengemasan. Jurnal teknologi dan Industri Pangan 17(1): 1-11. 